\title{
BM Global Health Determinants of adherence to antiretroviral therapy among HIV-positive adults in sub-Saharan Africa: a systematic review
}

\author{
Tessa Heestermans, ${ }^{1}$ Joyce L Browne, ${ }^{1}$ Susan C Aitken, ${ }^{2,3}$ Sigrid C Vervoort, ${ }^{4}$ \\ Kerstin Klipstein-Grobusch ${ }^{1,5}$
}

To cite: Heestermans $\mathrm{T}$, Browne JL, Aitken SC, et al. Determinants of adherence to antiretroviral therapy among HIV-positive adults in subSaharan Africa: a systematic review. BMJ Global Health 2016;1:e000125 doi:10.1136/bmjgh-2016000125

- Additional material is available. To view please visit the journal (http://dx.doi.org/ 10.1136/bmjgh-2016000125).

Received 12 July 2016 Revised 30 October 2016 Accepted 1 November 2016

CrossMark

For numbered affiliations see end of article.

Correspondence to

Dr Joyce L Browne;

J.L.Browne@umcutrecht.nl

\section{ABSTRACT}

Objective: The rapid scale up of antiretroviral treatment (ART) in sub-Saharan Africa (SSA) has resulted in an increased focus on patient adherence. Non-adherence can lead to drug-resistant HIV caused by failure to achieve maximal viral suppression. Optimal treatment requires the identification of patients at high risk of suboptimal adherence and targeted interventions. The aim of this review was to identify and summarise determinants of adherence to ART among HIV-positive adults.

Design: Systematic review of adherence to ART in SSA from January 2002 to October 2014.

Methods: A systematic search was performed in 6 databases (PubMed, Cochrane Library, EMBASE, Web of Science, Popline, Global Health Library) for qualitative and quantitative articles. Risk of bias was assessed. A meta-analysis was conducted for pooled estimates of effect size on adherence determinants.

Results: Of the 4052 articles screened, 146 were included for final analysis, reporting on determinants of 161922 HIV patients with an average adherence score of $72.9 \%$. Main determinants of non-adherence were use of alcohol, male gender, use of traditional/ herbal medicine, dissatisfaction with healthcare facility and healthcare workers, depression, discrimination and stigmatisation, and poor social support. Promoters of adherence included counselling and education interventions, memory aids, and active disclosure among people living with HIV. Determinants of health status had conflicting influence on adherence. Conclusions: The sociodemographic, psychosocial, health status, treatment-related and intervention-related determinants are interlinked and contribute to optimal adherence. Clinics providing ART in SSA should therefore design targeted interventions addressing these determinants to optimise health outcomes.

\section{INTRODUCTION}

Around 36.7 million people worldwide are currently living with HIV, of which 52\% reside in sub-Saharan Africa (SSA). ${ }^{1}$ With the introduction of antiretroviral therapies

\section{Key questions}

What is already known about this topic?

- Rapid scale-up of antiretroviral therapy (ART) resulted in the highest number of HIV-positive people using ART worldwide. Non-adherence to ART is the most common reason for treatment failure.

- Several systematic reviews have addressed determinants of adherence and showed determinants of adherence to differ per region of the world.

\section{What are the new findings?}

- This systematic review combined quantitative and qualitative articles to determine predictors for (non-)adherence. Main determinants identified for non-adherence were use of alcohol, male gender, use of traditional/herbal medicine, dissatisfaction with healthcare facility and healthcare workers, depression, discrimination and stigmatisation, and poor social support. Promoters of adherence included counselling and education interventions, memory aids, and active disclosure of HIV status.

- Qualitative articles provided insights into underlying reasons for identified determinants for (non-)adherence

\section{Recommendations for policy}

- A thorough understanding of factors associated with ART (non-)adherence allows for targeted interventions. We propose a number of interventions that could be implemented in healthcare services throughout sub-Saharan Africa to increase ART adherence.

(ARTs), HIV is increasingly becoming a chronic manageable disease. ${ }^{2}$ As a reflection of global roll-out efforts, the number of people living with HIV and receiving ART has increased by a third since 2013 and in 2015 about 17 million people received ART globally. Treatment success requires both a 
sustainable supply of ART to clinics and lifelong adherence to treatment by patients. ${ }^{1}{ }^{3}{ }^{4}$ The importance of improving treatment adherence has resulted in a vast number of publications focussing on this topic.

Non-adherence is the most common reason for treatment failure, ${ }^{5}$ with potential risk to develop drug resistance through suboptimal viral suppression. Subsequent transmission of first-line ART-resistant HIV strains increases demand for second-line treatment often associated with poorer patient health outcomes and increasing healthcare costs. ${ }^{5-7}$ For these reasons, a thorough understanding of determinants of adherence to ART are paramount. $^{8}$

Studies on ART adherence showed that predictors and risk factors differ per region of the world, necessitating context-specific development of non-adherence profiles. ${ }^{9} 10$ This will enable healthcare providers to offer tailored care for patients at risk of non-adherence. ${ }^{11}$ The objective of this study was to identify and summarise determinants of adherence to ART among HIV-positive adults in SSA. For a comprehensive overview, both qualitative and quantitative studies were included, ${ }^{12}$ as qualitative studies may identify key themes not found, described or discussed in larger quantitative studies.

\section{METHODS}

\section{Protocol and registration}

The systematic review was conducted in accordance with the PRISMA guidelines ${ }^{13}$ and the Cochrane Handbook for Systematic reviews; ${ }^{14}$ the study protocol was registered in PROSPERO (ID: CRD42014014476).

\section{Eligibility criteria, information sources and search strategy}

A systematic literature search was performed in the following electronic bibliographic databases: PubMed/ MEDLINE, The Cochrane Library, EMBASE, Web of Science, POPLINE, and the Global Health Library for all publications up to 27 October 2014. Search terms composed of MeSH and combined text for domain: 'HIV positive adults receiving ART in SSA', outcome 'Patient Compliance' and determinant 'Risk factors', 'Determinants' or 'Predictors'. For the complete search strategy see online supplementary data 1 . Filters were applied to exclude articles regarding infants, children and geographical locations other than SSA. All duplicates were removed using EndNote X7. ${ }^{15}$ No restriction based on year of publication, study design or language was applied. Given the comprehensive approach of the search, references were not checked, except those from a recent global systematic review, ${ }^{11}$ which did not yield additional articles.

\section{Study selection}

Titles and abstracts were independently screened for inclusion eligibility by two out of three reviewers $(\mathrm{TH}$, JLB, SCA). Inclusion criteria were: study population of 15 years or older, living in SSA, HIV-positive, currently receiving ART, and available adherence information. Age cut-off was based on previous systematic reviews and WHO/UNICEF Health Indicator guideline. ${ }^{16}$ Studies reporting on non-SSA populations were only included if the abstract indicated data were presented stratified for SSA participants. Eligible studies could be qualitative and/or quantitative. Animal, biomedical studies, case reports, non-peer-reviewed published reports of proceedings, conference abstracts, secondary analyses, without main focus on the region of SSA and studies that are written in neither English nor Dutch were excluded. Discrepancies between reviewers in this process were discussed and resolved by full-text evaluation. In case of incomplete data or unavailable full-text articles, two attempts were made to contact the corresponding author via email, no reaction resulted in exclusion of the study. Post hoc, a random $10 \%$ of 332 articles excluded based on region was assessed if the article contained any results for SSA. This was not the case.

\section{Data collection process and data items}

Data extraction was performed using a standardised data extraction form. For each article, name of the first author, publication year, country and geographical region, that is, Central-Africa, East-Africa, Southern Africa and West-Africa following the index of National Library of Medicine-Medical Subject Headings, ${ }^{17}$ study design, aim of study, study setting, adherence outcome, sample size, treatment status (initiating or already on ART), adherence assessment method and determinants/risk factor outcome were retrieved. Determinants were coded according to themes: sociodemographic and socioeconomic, treatment and health facilities, psychosocial, health status, and counselling and education interventions. These themes were adjusted where necessary in the writing process to assure that all determinants fitted within the framework.

Data extraction was carried out by a single reviewer (TH), who was not blinded for journal and author details. If clarifications on data extraction were needed, one of the two reviewers was contacted (JLB, SCA). Ten per cent of the qualitative studies were randomly controlled for uniformity in data extraction by a second reviewer (SCV). If data from the same study were used in multiple articles, the article reporting on the largest sample size or data source was used. For longitudinal studies, adherence measurement of the first time point was used to facilitate comparability across studies and to reduce loss to follow-up bias.

\section{Quality assessment and risk of bias in individual studies Quantitative studies}

For quality assessment of quantitative studies, an adapted version of the Cochrane Collaboration tool was applied as previously used in comparable reviews. ${ }^{18}{ }^{19}$ Studies were scored according to the following criteria: blinding of researcher or clinicians, selection of study population, completeness and origin of data 
(measurements performed by authors or database research), clarity of outcome definition, and whether and how confounders were taken into account. Risk of bias was assigned as low, high or unclear risk, according to the quality assessment tool previously described. ${ }^{14}$

\section{Qualitative studies}

Qualitative articles were scored on their risk of bias using a previously developed approach by Vervoort et $a l^{20}$ focussing on (1) participants of the study: nature of sample, recruitment strategy, population, sample size; (2) data collections: validity measurements, quality of data collector, interview type, data triangulation, thickness of data; and (3) data analysis: coding procedure, interpretation, validity measurements and triangulation analysis. Bias risk was assigned as one of the following levels: satisfactory (S), dubious or not mentioned (D), and unsatisfactory (U). The nature of the sample was described as convenience $(\mathrm{C})$ or purposive $(\mathrm{P})$.

\section{Mixed-method studies}

Studies which combined qualitative and quantitative methods were scored by both risk of bias assessments listed above.

\section{Summary measures, synthesis of results and risk of bias across studies}

Meta-analysis was performed to obtain a summary measure based on pooled estimates on adherence determinants derived from the respective ORs, relative risks (RR) and corresponding 95\% CI. If complete numbers of (non-) events were available, RRs were converted into ORs. If this was not possible, separate analyses for ORs and RRs were presented. Determinants reported in at least two studies were weighted based on the inverse of the variance as an estimate of statistical size. Owing to lack of reported risk estimates, not all studies included in this systematic review were suitable to be included. Statistical analyses were performed with RevMan V.5.3; (Review (RevMan) [Computer program]. Copenhagen: The Nordic Cochrane Centre The Cochrane Collaboration, 2014.) statistical significance was set at a two-sided $p$ value of $<0.05$. Heterogeneity was measured using the $\mathrm{I}^{2}$ statistic. ${ }^{21}$ Possible publication bias was assessed visually through funnel plots per determinant.

Determinants were described narratively when based on qualitative data, or if pooling of results was not possible due to the nature of the data, using a mixedmethods approach. For mixed-methods studies, results were analysed as either quantitative or qualitative depending on reported outcome.

\section{RESULTS}

A total of 4052 articles were identified through the systematic literature search (see flow diagram in figure 1). After removing duplicates, 2353 articles were screened on title and abstract, 2046 articles did not meet inclusion criteria and were excluded. After full-text assessment of the remaining 307 articles, a total of 146 articles were included for the final analysis. Of these 146 articles reporting on determinants of (non-)adherence, 112 reported on quantitative and 37 qualitative data, with 3 studies using mixed methods.

Study characteristics of these articles are presented in table 1 and online supplementary data 2. Included studies were published between 2003 and 2014, and
Figure 1 Flow diagram of the study selection for inclusion in the systematic review on determinants of adherence to ART in SSA. ART, antiretroviral treatment; SSA, sub-Saharan Africa.

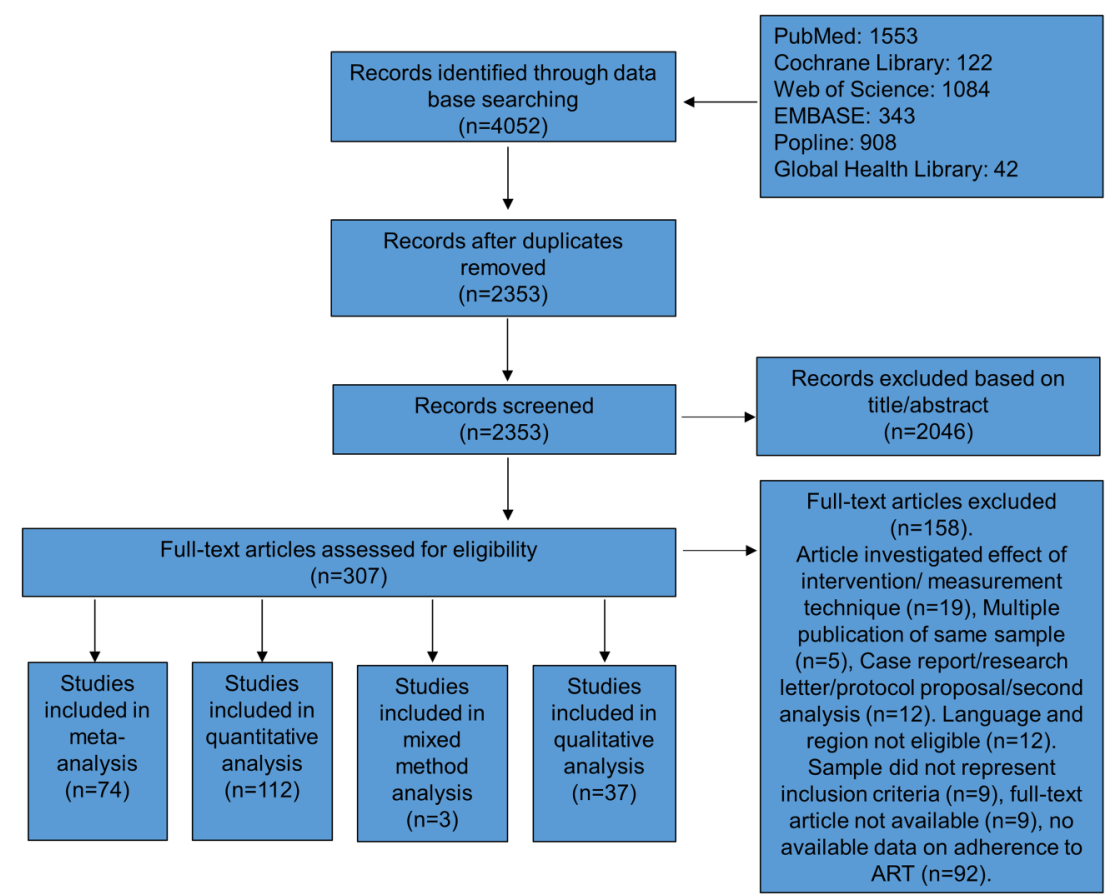


Table 1 Overview of characteristics of studies on adherence of antiretroviral treatment (ART)

\begin{tabular}{llc}
\hline $\begin{array}{l}\text { Characteristics of } \\
\text { studies on adherence } \\
\text { to ART }\end{array}$ & Group & $\mathbf{N}=(\%)$ \\
\hline Study type & Cohort & $44(27)$ \\
& $\begin{array}{l}\text { Cross-sectional } \\
\text { Qualitative }\end{array}$ & $73(45)$ \\
& Other & $77(24)$ \\
\hline $\begin{array}{l}\text { Retrospective/ } \\
\text { prospective }\end{array}$ & Prospective & $136(89)$ \\
\hline & Retrospective & $17(11)$ \\
\hline Region & $\begin{array}{l}\text { Central and } \\
\text { East-Africa }\end{array}$ & $74(45)$ \\
& Southern Africa & $56(35)$ \\
\hline Reported themes & West-Africa & $36(20)$ \\
quantitative & Sociodemographic & $75(31)$ \\
& Psychosocial & $40(21)$ \\
\hline & Health status & $25(14)$ \\
\hline & Treatment & $49(22)$ \\
\hline & Intervention & $12(10)$ \\
\hline & $\begin{array}{l}\text { No significant } \\
\text { determinants found }\end{array}$ & $8(2)$ \\
\hline
\end{tabular}

reported on 161922 participants. Seventy-four articles reported on Central and East-Africa, 56 on Southern Africa and 36 on West-Africa. The average adherence rate was $52.5 \%$ (adherence $100 \%$ ) and $72.9 \%$ (adherence $95 \%$ ).

\section{Bias assessment}

Overall the performance of risk of bias was reasonably well, with only a few studies reporting high risk of bias on one or more of the categories (25\% quantitative, $51.3 \%$ qualitative). Risk of bias assessment of the quantitative and qualitative studies is summarised in figure 2. Details for bias assessment for individual studies can be found in online supplementary files 3 and 4 .

For quantitative studies, blinding of researchers and selection of study population was frequently unclear $(69.6 \%$ and $49.1 \%)$. The other categories scored reasonably well, especially completeness of data and clear definitions of outcome $(86.6 \%$ and $92.9 \%)$. For qualitative studies, validity of measurements in data collection and data analysis were least well defined (62.1\%). Recruitment strategy was unclear in $56.8 \%$. Other categories scored reasonably well.

The funnel plots, where possible, showed on visual inspection some evidence of publication bias in smaller studies considering younger age, that is, 15-35 years, low or no education, and discrimination (see online supplementary data 4 ).

\section{Determinants of (non-)adherence}

Sociodemographic, socioeconomic and lifestyle factors Sociodemographic and socioeconomic determinants were reported in 105 studies.

Age was reported by 20 articles to be a determinant for adherence, with better adherence seen in older patients (>35 years) compared with younger patients. ${ }^{22-41}$

Eighteen studies reported gender influences on adherence. Eleven reported better adherence for women, ${ }^{31}{ }^{42-51}$ but six reported the opposite. ${ }^{22} 284152-54$ Among men who had sex with men lower adherence was reported..$^{55}$

Lower levels of education corresponded with nonadherence, ${ }^{42} 4552535657$ and higher adherence was observed among patients with formal education. ${ }^{58-60}$ However, some articles reported the opposite..$^{41-63}$

Alcohol use increased the risk of

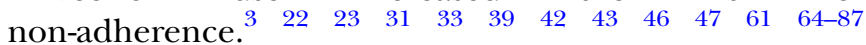
Suggested reasons were that patients may forget to take their medication as a consequence of alcohol use. ${ }^{3367} 78$ Men may use alcohol to deny the reality of being HIV-positive. ${ }^{85}$

Religion was reported as both a barrier to and a promoter of adherence. ${ }^{33} 6771747982-85$ 88-102 Belief and faith that God provided the knowledge to make ART acts was observed to promote adherence, ${ }^{71} \quad 82 \quad 9293$ whereas studies reporting belief in religious cures for HIV over conventional medical approaches observed increased non-adherence. ${ }^{71} 8293$

Employment showed conflicting outcomes; nonadherence was observed to be higher in unemployed $^{54616496}$ and employed ${ }^{31} 747896103$ people. Similarly, both higher income and poverty were associated with non-adherence. ${ }^{3} 2842474951525659858796$ 104-107 Financial challenges, including transport costs, health facility costs and financial insecurity were associated with non-adherence. ${ }^{40} 54 \quad 5962646971 \quad 78 \quad 83858894 \quad 101 \quad 107-117$ Food insecurity resulted in non-adherence through two mechanisms: stopping ART when food was unavailable to avoid aggravated (gastrointestinal) side effects, or because taking ART when insufficient food is available increased $\begin{array}{lllllllll}\text { hunger. }^{31} & 49 & 53 & 59 & 64 & 65 & 67 & 69 & 71\end{array}$ $727882838595102105107109110115118-120$

Other predictors reported to be associated with (non-) adherence were: distance to clinic, ${ }^{29} 3741528485111121$ having children, 88 93 $106 \quad 110 \quad 114-116 \quad 122$ geographical area, ${ }_{45}^{58} 96 \quad 117{ }^{123}$ marital status, ${ }^{41} 53 \quad 586164 \quad 6568104$ number of sexual partners, ${ }^{47} 124$ travelling, ${ }^{33} 71105109110$ forgetting to take medication, ${ }^{59} 718384$ hospital versus government ART initiative, ${ }^{51}$ living situation, ${ }^{87}$ tobacco use, ${ }^{47}$ unable to maintain healthy lifestyle ${ }^{122}$ and language barriers. ${ }^{36}$

\section{Treatment and health facilities}

Seventy-five articles reported treatment determinants affecting adherence. The majority of these mentioned the negative influence of side effects on adherence, such as chronic diarrhoea and body shaping effects, 


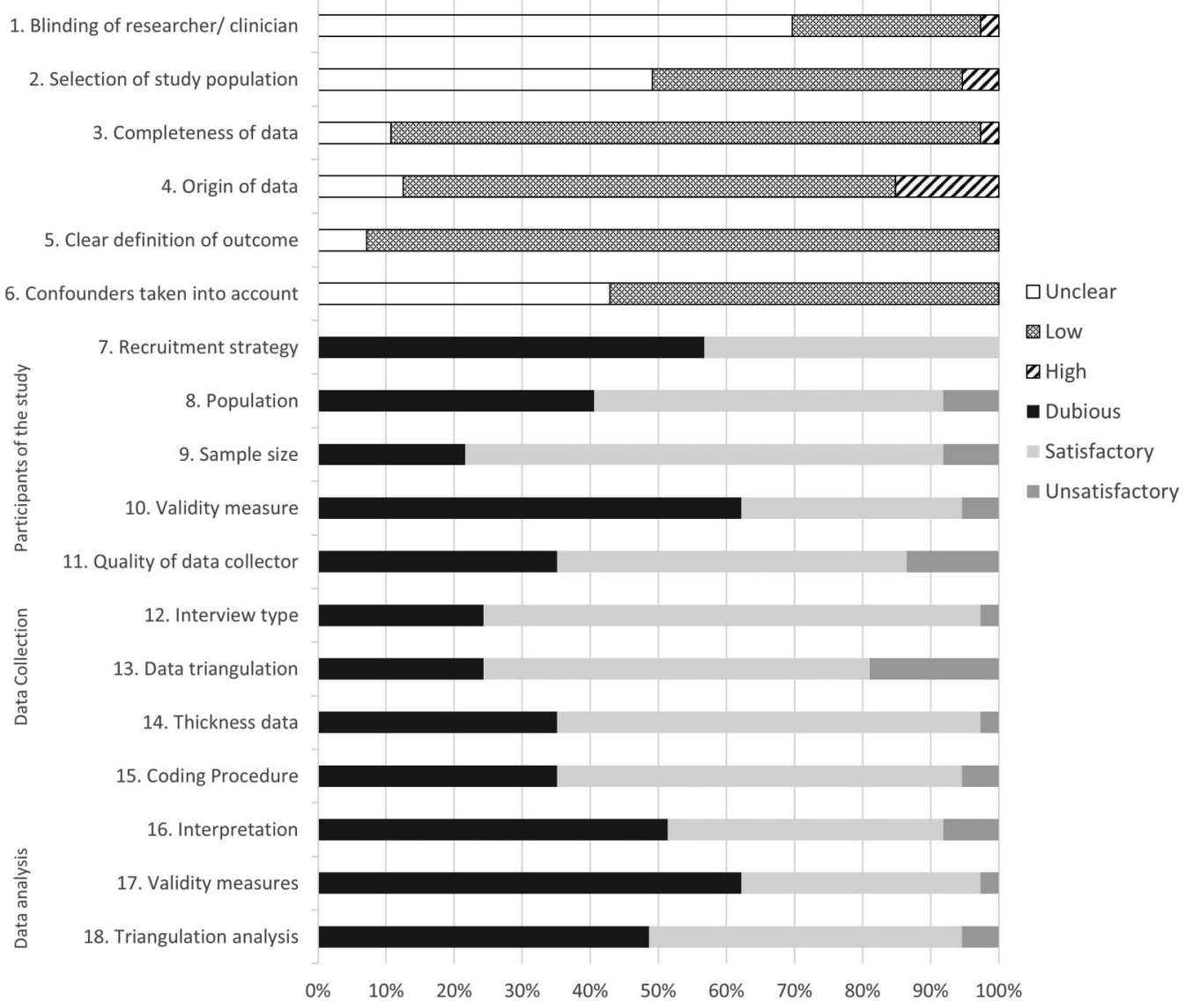

Figure 2 Summary risk of bias assessment for qualitative (items 1-6) and qualitative ${ }^{7-18}$ studies on adherence to ART. ART, antiretroviral treatment.

giving rise to the fear of involuntary disclosure of HIV

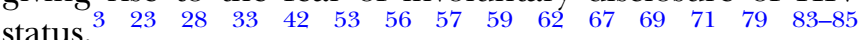
889495102107110114115120121 125-130 The second most reported determinant was the influence of healthcare workers on patient adherence. A confidential and good relationship with healthcare providers resulted in better adherence. Non-adherence was seen when patients encountered unpleasant experiences with clinic staff, including rudeness, condemnation and fatigue. $^{7} 30335965-67787983-858894101109113116122131$

Health facility determinants associated with nonadherence included experiencing no privacy at the facility, due to crowded pharmacies, consultations with multiple patients and lost files. Long waiting times and limited clinic hours were reported to lead to non-adherence, especially for employed people who would need to take time off to collect their medication. ${ }^{3} \quad \begin{array}{lllllllll}7 & 33 & 65 & 67 & 69 & 78 & 79 & 83-85\end{array}$ 87889497101107109

Patients positive perceptions of ART, such as a strong belief in value of treatment and understanding importance of adherence, ${ }^{33} 8394109114116118122$ were associated with adherence, whereas rumours and false beliefs about ART, including that ART can cause harm and is a sexual stimulant, were associated with non-adherence. 8384102109114120126

Duration of treatment was observed to be associated with both adherence ${ }^{29} \quad \begin{array}{lllllllll}56 & 64 & 74 & 124 & 132 & 133 & \text { and non- }\end{array}$ adherence. $^{23} \quad 38 \quad 52 \quad 6972 \quad 75 \quad 134$ Studies reporting better adherence over time suggested that long-term experience with ART results in better knowledge and strategies to incorporate ART use in daily life, social support, longer exposure to healthcare services, returning of strength and increased ability to manage side effects. $^{29} 56 \quad 64{ }^{124}$ Reasons for increased non-adherence could be the experience of no instant consequences for non-adherence and risk behaviour like smoking and use of alcohol. ${ }^{69}$ A proposed concept for adherence support interventions to reduce the consequences of duration of adherence was a shift towards promoting adherence as a means to live, rather than only survive. ${ }^{23} 75 \quad 134$ Other treatment and healthcare facility-related determinants were: pill burden as a predictor for nonadherence, ${ }^{36} 38396484102106110115130$ change in medication or treatment, ${ }^{56} \quad \begin{array}{llllll}74 & 83 & 109 & 114 & \text { medication }\end{array}$

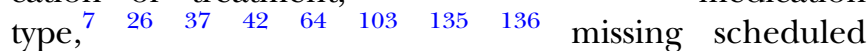
visits, $^{30} 4066137$ pharmacy stock out, ${ }^{40} 42 \quad 4867$ dietary instructions, ${ }^{100}$ study type ${ }^{136}$ and unclearly defined ART dosage. $^{3} 102$

\section{Psychosocial}

Seventy-three studies found psychosocial determinants affecting adherence. Disclosure, whereby people living with HIV hide or skip their medication to avoid disclosure of HIV status, was described most often in relation to non- 
$\begin{array}{llllllll}\text { adherence }^{4} & 22 & 26 & 39 & 41 & 50 & 61 & 68\end{array}$

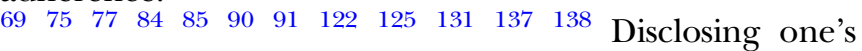
HIV status to spouse, children and others has been observed to be a predictor of receiving support and was observed to be associated with adherence. $\begin{array}{lllllllllllll}33 & 37 & 49 & 62 & 67 & 78 & 83 & 85 & 111 & 115 & 116 & 131 & 139\end{array}$ Similarly, material, emotional and social support

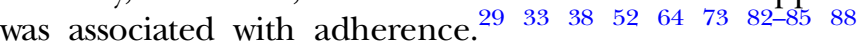
94101107109113115119125129131 140-143

Fear of discrimination and/or experiencing stigma were determinants of non-adherence. This included being laughed at, exclusion from activities, being fired and alienation. ${ }^{3} 33 \quad 43 \quad 59 \quad 64 \quad 65 \quad 67 \quad 78 \quad 83 \quad 85 \quad 88 \quad 97 \quad 103 \quad 107 \quad 109$ 113-115 120122125130144145 Depression was found to be a predictor for non-adherence, and included reasons such as 'ready to die' and 'loss of hope of ever getting better'. 2543717377828794105113120140142 146-149 Further factors strongly influencing adherence include coming to terms and acceptance of illness, for example, people with a desire to live and take care of children, and fear of returning to pre-ART health state. ${ }^{67828494110116122144}$ Conversely, difficulty in coming to terms and lack of belief in existence of HIV, and not feeling sick were barriers to adherence. ${ }^{33}$ Other determinants affecting both adherence and non-adherence were cognitive impairment, ${ }^{73} 128143$ internalised stigma, ${ }^{43687382}$ known use of ART and/or HIV status of others, ${ }^{4} 496972134139$ psychological distress, ${ }^{72} 150$ trauma, ${ }^{109142} 151$ masculinity, ${ }^{85} 122152$ sharing medication, ${ }^{35}{ }^{94}$ lack of commitment to therapy, ${ }^{6385105119120}$ isolation from family, ${ }^{115}$ caring for family, $^{114}{ }^{121}$ wanting to return to life before ART, ${ }^{119}$ being accused of infecting others, ${ }^{102}$ psychiatric care service $^{126}$ and stress. ${ }^{83}$

\section{Health status}

The most common health status-related determinant was perceived health status. Experiencing improved health on ART, increased confidence in medication, weight gain and being able to return to work were positively associated with adherence. ${ }^{3} \quad 33 \quad 44 \quad 47 \quad 82-85$ 889092101102 108-110113 115-117119129144 However, some studies noted that improved health could result in nonadherence if people believed to have been cured. $^{33} \quad 38 \quad 84 \quad 105 \quad 110 \quad 120 \quad 122 \quad 130 \quad 138$ Studies assessing adherence in relation to participant's CD4 cell count were conflicting. Both low and high CD4 counts were reported to increase and decrease adherence to ARTs. $^{23} 2532373896137153$

Adherence to ART could be decreased when a patient needs to cope with multiple ailments including malaria, diabetes and high blood pressure-especially when asymptomatic for HIV. ${ }^{47} 94 \quad 109 \quad 113 \quad 122 \quad 129$ The following determinants predicted non-adherence to a lesser extent: body mass index, ${ }^{26} 95154 \mathrm{~TB},{ }^{50} 7374$ WHO clinical stage, ${ }^{265675}$ CDC staging criteria, ${ }^{133}$ haemoglobin, ${ }^{32}$ immune reconstitution inflammatory syndrome event ${ }^{81}$ and viral load. ${ }^{95}$

\section{Counselling and education interventions}

Counselling and education were mentioned by 20 articles to be associated with adherence. Adherence training commonly consisted of strategies to cope with the medication and its side effects. Patients who had poor knowledge of basic HIV concepts due to no or low-quality counselling were at higher risk of non$\begin{array}{lllllll}\text { adherence. }^{25} & 64 & 66 & 78 & 79 & 82 & 84-86\end{array}$ 889294101102107109110116131

The use of memory aids like mobile phones, radio alarms, watches, clocks, reminders of children and pill boxes were observed to be associated with adherence, 4488109110113114119140155 likewise implementation of ART in daily routines; not being able to do so was associated with non-adherence. $^{3} 296985102105109110125144$ Having a treatment partner or clinic buddy was observed to be associated with adherence. ${ }^{32} 85112114139144156$ Receiving support by non-governmental organisation/ government $^{83-85}$ and adherence self-efficacy ${ }^{122}$ were also reported determinants of adherence.

A total of 14 studies found no significant determinants of adherence. ${ }^{157-165}$

\section{Meta-analysis}

Meta-analysis could be performed for 25 determinants: 12 sociodemographic and socioeconomic factors, 5 psychosocial, 4 treatment-related and 2 health status and intervention-related determinants. Results are summarised in figure 3, sample sizes and number of studies included per determinant are presented in online supplementary data 5 .

\section{Sociodemographic and socioeconomic factors}

Determinants associated with a protective effect on adherence were not drinking alcohol $(\mathrm{OR}=0.41 ; 95 \% \mathrm{CI}$ 0.27 to $\left.0.65 ; \mathrm{I}^{2}=38 \%\right)^{22} 39$ and non-use of herbal/traditional medicine/treatment $(\mathrm{OR}=0.56 ; 95 \%$ CI 0.38 to $0.83) .^{100}$

Non-adherence was associated with the following determinants: use of alcohol $(\mathrm{OR}=1.78 ; 95 \%$ CI 1.51 to 2.09; I $\left.{ }^{2}=39 \%\right),{ }^{23} 466164667274768687$ binge drinking $(\mathrm{OR}=2.25 ; \quad 95 \% \quad \mathrm{CI} \quad 1.92 \quad$ to 2.65 ; $\left.\mathrm{I}^{2}=18 \%\right),{ }^{31} 4246476570737586$ male gender (OR=1.73; $95 \%$ CI 1.34 to $\left.2.23 ; \mathrm{I}^{2}=60 \%\right), 22314247485161$ younger age $\quad(15-35$ years; $\quad \mathrm{OR}=1.61 ; 95 \%$ CI 1.25 to 2.06 ;

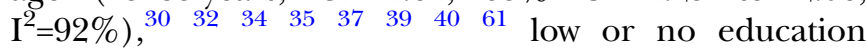
$(\mathrm{OR}=1.80 ; \quad 95 \% \quad \mathrm{CI} \quad 1.09 \quad$ to $\quad 2.98$ $\left.\mathrm{I}^{2}=81 \%\right),,^{30} 75 \quad 789397 \quad 114118$ use of herbal/traditional medicine/treatment $(\mathrm{OR}=2.65 ; 95 \%$ CI 1.18 to 5.95 ; $\left.\mathrm{I}^{2}=78 \%\right),{ }^{90} 91959698$ low income or living below poverty level $\quad(\mathrm{OR}=3.36 ; \quad 95 \% \quad \mathrm{CI} \quad 2.22$ to 5.93 ; $\left.\mathrm{I}^{2}=66 \%\right),{ }^{28} 42475296104$ costs forming barriers to treatment $\quad(\mathrm{OR}=3.09 ; \quad 95 \% \quad$ CI $\quad 1.78$ to 5.37 ; $\left.\mathrm{I}^{2}=59 \%\right),{ }^{40} 5962 \quad 111 \quad 117$ urban treatment site or urban residence $\left(\mathrm{OR}=3.32 ; 95 \% \text { CI } 2.26 \text { to } 4.87 ; \mathrm{I}^{2}=0 \%\right)^{45} 5896$ and food insecurity $(\mathrm{OR}=1.95 ; 95 \%$ CI 1.65 to 2.29; $\left.\mathrm{I}^{2}=13 \%\right)$. $^{314953657295}$ 


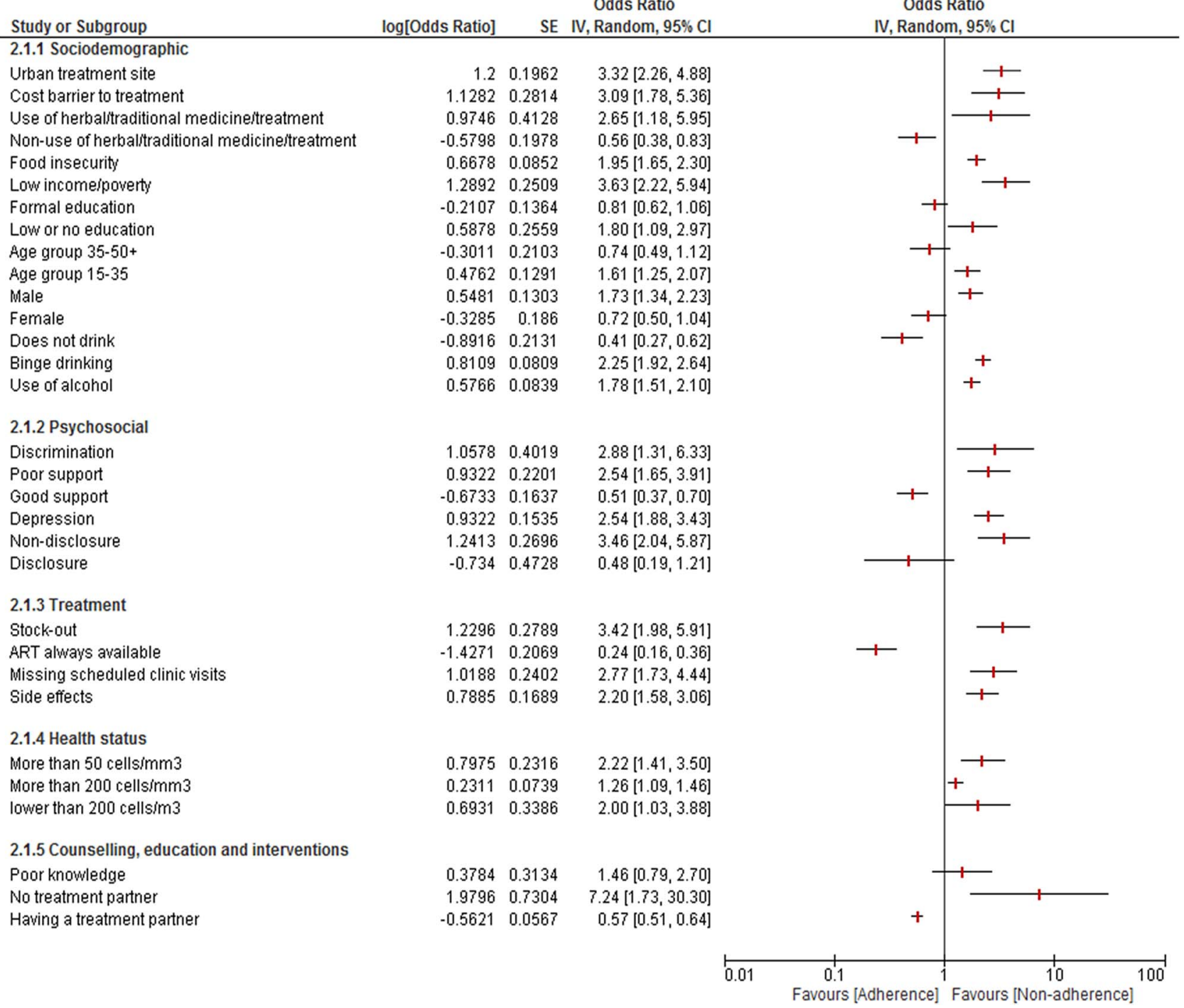

Figure 3 Forrest plot meta-analysis for determinants of non-adherence to ART. ART, antiretroviral treatment.

Other determinants were not significantly related to adherence, for example, formal education, (un)employment, high income and marital status. However, female gender and older age ( 35 to $50+$ years) showed trends in favouring adherence $(\mathrm{OR}=0.72 ; 95 \%$ CI 0.50 to 1.03 ; $\left.\mathrm{I}^{2}=79 \%\right)^{26} 36 \quad 38$ and $(\mathrm{OR}=0.74 ; 95 \%$ CI 0.49 to 1.11 ; $\left.\mathrm{I}^{2}=86 \%\right),{ }^{22} 2325272830$ respectively.

\section{Treatment and health facilities}

Reliable ART availability $(\mathrm{OR}=0.24 ; 95 \%$ CI 0.16 to $0.37)^{40}$ was associated with increased adherence, whereas pharmacy stock-out was associated with nonadherence $\left(\mathrm{OR}=3.42 ; 95 \%\right.$ CI 1.98 to $\left.5.90 ; \mathrm{I}^{2}=0 \%\right) .{ }^{42} 48$ Other determinants associated with non-adherence were side effects $(\mathrm{OR}=2.20 ; \quad 95 \% \quad \mathrm{CI} \quad 1.58$ to 3.07 ; $\left.\mathrm{I}^{2}=76 \%\right)^{23} 42535762121126128129165$ and missing scheduled clinic visits (OR=2.77; 95\% CI 1.73 to 4.43; $\left.\mathrm{I}^{2}=55 \%\right)$. Non-significant determinants were: change in regimen and/or treatment, and perceived health status by patients.

\section{Psychosocial}

Adherence was associated with good social support $\left(\mathrm{OR}=0.51 ; 95 \%\right.$ CI 0.37 to $\left.0.71 ; \mathrm{I}^{2}=0 \%\right) .{ }^{129}{ }^{140}{ }^{141}$ Determinants predictive for non-adherence were: nondisclosure to others $(\mathrm{OR}=3.46 ; 95 \%$ CI 2.04 to 5.89 ; $\left.\mathrm{I}^{2}=66 \%\right),{ }^{49} 52536466137138$ depression $(\mathrm{OR}=2.54 ; 95 \%$ CI 1.65 to $\left.3.91 ; \mathrm{I}^{2}=52 \%\right),{ }^{25} 437387140147-149$ poor social support $\quad(\mathrm{OR}=2.54 ; \quad 95 \% \quad$ CI $\quad 1.65$ to 3.91 ; $\left.\mathrm{I}^{2}=31 \%\right)^{29} \quad 64 \quad 73 \quad 143$ and discrimination $(\mathrm{OR}=2.88 ; 95 \%$ CI 1.31 to $\left.6.36 ; \mathrm{I}^{2}=73 \%\right) .{ }^{43} 65103145$ Psychological distress was not related to ART adherence. ${ }^{72} 73$

\section{Health status}

Contrary to the narrative assessment, $\mathrm{CD} 4$ count was predictive for non-adherence in the meta-analysis: CD4 $\geq 200$ cells $/ \mathrm{mm}^{3} \quad(\mathrm{OR}=1.26 ; 95 \%$ CI 1.09 to 1.46 ; $\left.\mathrm{I}^{2}=40 \%\right)$, 25 $323796 \mathrm{CD} 4 \leq 200$ cells $/ \mathrm{mm}^{3} \quad(\mathrm{OR}=2.00 ; 95 \%$ CI 1.03 to $\left.3.87 ; \mathrm{I}^{2}=30 \%\right)^{23} 137$ and $\mathrm{CD} 4 \leq 50$ cells $/ \mathrm{mm}^{3}$ $(\mathrm{OR}=2.22 ; 95 \%$ CI 1.41 to 3.50$){ }^{153}$ 


\section{Counselling and education interventions}

Having no treatment partner was associated with increased likelihood of non-adherence $(\mathrm{OR}=7.24 ; 95 \%$ CI 1.73 to 30.3$),{ }^{156}$ conversely having a treatment partner $\left(\mathrm{OR}=0.57 ; 95 \% \text { CI } 0.51 \text { to } 0.64 ; \mathrm{I}^{2}=0 \%\right)^{32} 53$ was associated with increased adherence.

\section{DISCUSSION}

Our systematic review complements the existing body of literature, and identified numerous determinants influencing adherence to antiretroviral medication in SSA. Significant determinants for quantitative and qualitative studies of non-adherence were the use of alcohol, male gender, use of traditional/herbal medicine, dissatisfaction with healthcare facility and healthcare workers, depression, discrimination and stigmatisation, and poor social support. Promoters of adherence included counselling and education interventions, memory aids, and active disclosure among people with HIV. Determinants of health status had conflicting influence on adherence.

Langebeek et $a l^{11}$ performed a meta-analysis on predictors of adherence globally, and Mills $e t a l^{12}$ compared developed and developing countries. A number of comparable determinants were found including substance abuse, concerns about ART or necessity of ART, satisfaction with the healthcare provider, depression, stigma, social support, financial constraints and pill burden. ${ }^{11}$ Our approach focussed on determinants of adherence for people living with HIV in SSA, who constitute about two-third of HIV patients worldwide, and as such we were able to identify specific determinants relevant for this setting, including, for example, food insecurity, use of traditional herbs and medicine, and stigma. Trust and satisfaction with a healthcare provider may be more important in SSA countries with a low and medium Human Development Index, ${ }^{11}$ as well as issues of access to healthcare, impact of financial constraints, and disruption of services and medication distribution. ${ }^{12}$

A strength of this systematic review is our mixedmethods approach, in which we combined a meta-analysis with a narrative review and included both quantitative and qualitative studies and the comprehensive search undertaken including databases that specifically focus on lowincome and middle-income country-based research.

A number of limitations should be considered. Importantly, this systematic review and inference of results is limited by the quality of the individual papers underlying the process. For example, a high risk of bias was introduced with the limited consideration of confounders on the association between determinant and exposure. Likewise, if studies did not ask about determinants, this information was not captured in this review, a rather general limitation of studies. As the majority of data extractions were completed by one reviewer, this could have introduced bias; however, all questions related to inclusion/exclusion of a study were discussed with the investigator team.

We observed significant heterogeneity in measurements and definition of optimal adherence and inclusion criteria for participants in the different studies. Various methods were employed to assess adherence: self-report questionnaires, pill count, pharmacy refill, visual analogue scale, viral load, CD4 cell count, Center for Adherence Support Evaluation (CASE), Community Programs for Clinical Research on AIDS (CPCRA), electronic medication monitors and the AIDS clinical trial group adherence scale. Although some have been validated, no consensus exists about the extent of their validity or gold standard. Direct measurement of blood drug level concentration was not used in any of the studies. We considered the heterogeneity in the assessment of risk of bias by assessing all varieties and their appropriateness and applicability within the paper. For example, self-report has been validated for adherence assessment in rural areas, and therefore was considered a low risk of bias method in this review, even though the exact execution will determine its ultimate validation. Future studies should consider seeking consensus for the optimal tool to assess adherence, building on the available assessment of methods ${ }^{166-168}$ and considering practical limitations for application in SSA settings. For example, the 30-day analogue scale may be a promising approach for its convenient and reliable results. ${ }^{168-172}$

\section{Clinical implications}

Our comprehensive overview of determinants that affect (non-)adherence could be of great use to optimise ART clinical service and adherence support within the current healthcare systems. Identified determinants allow for tailored support and interventions to be developed, evaluated and when effective, implemented in regions with scarce resources.

Interaction/clustering observed between determinants allow clinics to identify high-risk individuals most likely to benefit from targeted interventions. In fact, this is an active area of research and ample examples exist for specific evidence-based interventions.

For people living with HIV receiving ART who struggle with adherence as a result of the burden of monthly visits to crowded clinics, travel costs and/or time off work, a support group of several other persons receiving ART could be helpful whereby the group members take turns collecting medications. ${ }^{173} 174$

For the strongest individual predictor of (non-)adherence, alcohol use, a number of interventions have been identified. These include brief health provider-initiated alcohol interventions for people living with $\mathrm{HIV}^{8175}$ and the WHO-proposed intervention framework with brief consultations focussed on alcohol reduction. ${ }^{176}$ Interventions focussed on younger patients include personalised, interactive and daily SMS reminders. ${ }^{177}$ Group-based counselling intervention for depression can potentially increase adherence. ${ }^{178}$ Other important interventions focus on improving quality of healthcare delivered in a system usually underfunded and overstretched. These include decentralisation of ART 
services, and task shifting from doctors and nurses to counsellors or community health workers. ${ }^{179} 180$

In conclusion, determinants of (non)-adherence in SSA identified in this review could facilitate the development, evaluation and implementation of targeted interventions. Given the increased accessibility of ART in SSA, optimising adherence will improve the health of millions of people living with HIV.

\begin{abstract}
Author affiliations
${ }^{1}$ Julius Global Health, Julius Center for Health Sciences and Primary Care, University Medical Center Utrecht, Utrecht, The Netherlands

${ }^{2}$ Ndlovu Research Consortium, Elandsdoorn, South Africa

${ }^{3}$ Department of Medical Microbiology, University Medical Centre Utrecht, The Netherlands

${ }^{4}$ University Medical Centre Utrecht Cancer Center, Utrecht, The Netherlands

${ }^{5}$ Division of Epidemiology \& Biostatistics, School of Public Health, Faculty of Health Sciences, University of the Witwatersrand, Johannesburg, South Africa
\end{abstract}

Handling editor Seye Abimbola

Acknowledgements The authors would like to thank Professor Dr Rob Scholten for his advice on the meta-analysis conducted for the current study.

Competing interests None declared.

Provenance and peer review Not commissioned; externally peer reviewed.

Data sharing statement No additional data are available.

Open Access This is an Open Access article distributed in accordance with the Creative Commons Attribution Non Commercial (CC BY-NC 4.0) license, which permits others to distribute, remix, adapt, build upon this work noncommercially, and license their derivative works on different terms, provided the original work is properly cited and the use is non-commercial. See: http:// creativecommons.org/licenses/by-nc/4.0/

\section{REFERENCES}

1. Global Aids Update 2016. 2016. http://www.unaids.org/en/ resources/documents/2016/Global-AIDS-update-2016

2. Dorfman D, Saag MS. Decline in locomotor functions over time in HIV-infected patients. AIDS 2014;28:1531-2.

3. Vyankandondera J, Mitchell K, Asiimwe-Kateera B, et al. Antiretroviral therapy drug adherence in Rwanda: perspectives from patients and healthcare workers using a mixed-methods approach. AIDS Care 2013;25:1504-12.

4. Dahab M, Charalambous S, Karstaedt AS, et al. Contrasting predictors of poor antiretroviral therapy outcomes in two South African HIV programmes: a cohort study. BMC Public Health 2010;10:1-14.

5. Bangsberg DR. Preventing HIV antiretroviral resistance through better monitoring of treatment adherence. J Infect Dis 2008;197 (Suppl 3):S272-8.

6. Mbuagbaw L, Thabane L, Ongolo-Zogo P, et al. Trends and determining factors associated with adherence to antiretroviral therapy (ART) in Cameroon: a systematic review and analysis of the CAMPS trial. AIDS Res Ther 2012;9:1-10.

7. Garang PG, Odoi RA, Kalyango JN. Adherence to antiretroviral therapy in conflict areas: a study among patients receiving treatment from Lacor Hospital, Uganda. AIDS Patient Care STDS 2009;23:743-7.

8. Nakimuli-Mpungu E, Bass JK, Alexandre P, et al. Depression, alcohol use and adherence to antiretroviral therapy in sub-Saharan Africa: a systematic review. AIDS Behav 2012;16:2101-18.

9. Ware NC, Idoko J, Kaaya S, et al. Explaining adherence success in sub-Saharan Africa: an ethnographic study. PLoS Med 2009;6: e11.

10. Mills EJ, Nachega JB, Buchan I, et al. Adherence to antiretroviral therapy in sub-Saharan Africa and North America: a meta-analysis. JAMA 2006;296:679-90.

11. Langebeek N, Gisolf $E H$, Reiss $P$, et al. Predictors and correlates of adherence to combination antiretroviral therapy (ART) for chronic HIV infection : a meta-analysis. BMC Med 2014;12:142.
12. Mills E, Nachega J, Bangsberg D, et al. Adherence to HAART: a systematic review of developed and developing nation patient-reported barriers and facilitators. PLoS Med 2006;3:2039-64.

13. Moher D, Liberati A, Tetzlaff J, et al. Preferred Reporting Items for Systematic Reviews and Meta-Analyses. PLoS Med 2009;6:1-2.

14. Higgins JP, Green S, Deeks JJ, et al. The Cochrane Collaboration's tool for assessing risk of bias in randomized trials. 2008:187-325. http://eprints.whiterose.ac.uk/65834/

15. Thomson Reuters EndNote. EndNote Viewer X7.3.1 (Bld8614). 2014

16. WHO. Global AIDS Response Progress Reporting 2016. Geneva, Switzerland, 2016.

17. U.S. National Library of Medicine. Medical Subject Headings. NIH. 1999 (cited 25 February 2015). http://www.nlm.nih.gov.proxy.library. uu.nl/mesh/meshhome.htm

18. Browne JL, Schrier VJ, Grobbee DE, et al. HIV, antiretroviral therapy and disorders in pregnancy: a systematic review and meta-analysis. J Acquir Immune Defic Syndr 2015;70:91-8.

19. Calvert $\mathrm{C}$, Ronsmans C. HIV and the risk of direct obstetric complications: a systematic review and meta-analysis. PLoS ONE 2013;8:e74848.

20. Vervoort SC, Borleffs JC, Hoepelman Al, et al. Adherence in antiretroviral therapy: a review of qualitative studies. AIDS 2007;21:271-81

21. Deeks JJ. Chapter 9: Analysing data and undertaking. Cochrane Handbook for Systematic Reviews of Interventions Version 510 (updated March 2011) 2011:1-43.

22. Alemu $\mathrm{H}$, Haile Mariam $\mathrm{D}$, Tsui $\mathrm{AO}$, et al. Correlates of highly active antiretroviral therapy adherence among urban Ethiopian clients. Afr J AIDS Res 2011;10:263-70.

23. Elul B, Basinga $\mathrm{P}$, Nuwagaba-Biribonwoha $\mathrm{H}$, et al. High levels of adherence and viral suppression in a nationally representative sample of HIV-infected adults on antiretroviral therapy for 6, 12 and 18 months in Rwanda. PLOS ONE 2013;8:e53586.

24. Kunutsor S, Evans M, Thoulass J, et al. Ascertaining baseline levels of antiretroviral therapy adherence in Uganda: a multimethod approach. J Acquir Immune Defic Syndr 2010;55:221-4.

25. Memiah $\mathrm{P}$, Shumba $\mathrm{C}$, Etienne-Mesubi M, et al. The effect of depressive symptoms and CD4 count on adherence to highly active antiretroviral therapy in sub-Saharan Africa. J Int Assoc Provid AIDS Care 2014:13:346-52.

26. Muya AN, Geldsetzer P, Hertzmark E, et al. Predictors of nonadherence to antiretroviral therapy among HIV-infected adults in Dar es Salaam, Tanzania. J Int Assoc Provid AIDS Care 2015;14:163-71

27. Newman J, Iriondo-Perez J, Hemingway-Foday J, et al. Older adults accessing HIV care and treatment and adherence in the leDEA Central Africa Cohort. AIDS Res Treat 2012;2012:725713.

28. Rougemont M, Stoll BE, Elia N, et al. Antiretroviral treatment adherence and its determinants in Sub-Saharan Africa: a prospective study at Yaounde Central Hospital, Cameroon. AIDS Res Ther 2009;6:1-12.

29. Wakibi SN, Ng'ang'a ZW, Mbugua GG. Factors associated with non-adherence to highly active antiretroviral therapy in Nairobi, Kenya. AIDS Res Ther 2011;8:43

30. Watt MH, Maman S, Golin CE, et al. Factors associated with self-reported adherence to antiretroviral therapy in a Tanzanian setting. AIDS Care 2010;22:381-9.

31. Weiser SD, Palar K, Frongillo EA et al. Longitudinal assessment of associations between food insecurity, antiretroviral adherence and HIV treatment outcomes in rural Uganda. AIDS 2014;28:115-20.

32. Chi BH, Cantrell RA, Zulu I, et al. Adherence to first-line antiretroviral therapy affects non-virologic outcomes among patients on treatment for more than 12 months in Lusaka, Zambia. Int $J$ Epidemiol 2009:38:746-56.

33. Dahab M, Charalambous $\mathrm{S}$, Hamilton $\mathrm{R}$, et al. "That is why stopped the ART": patients' \& providers' perspectives on barriers to and enablers of HIV treatment adherence in a South African workplace programme. BMC Public Health 2008;8:63.

34. Nachega JB, Hislop M, Nguyen $\mathrm{H}$, et al. Antiretroviral therapy adherence, virologic and immunologic outcomes in adolescents compared with adults in Southern Africa. J Acquir Immune Defic Syndr 2009;51:65-71.

35. Nozaki I, Dube C, Kakimoto K, et al. Social factors affecting ART adherence in rural settings in Zambia. AIDS Care 2011;23:831-8

36. Orrell C, Bangsberg DR, Badri M, et al. Adherence is not a barrier to successful antiretroviral therapy in South Africa. AIDS 2003;17:1369-75. 
37. Charurat M, Oyegunle M, Benjamin R, et al. Patient retention and adherence to antiretrovirals in a large antiretroviral therapy program in Nigeria: a longitudinal analysis for risk factors. PLOS ONE 2010;5: e10584.

38. Diabaté S, Alary M, Koffi CK. Determinants of adherence to highly active antiretroviral therapy among HIV-1-infected patients in Côte d'Ivoire. AIDS 2007;21:1799-803.

39. Falang KD, Akubaka P, Jimam NS. Patient factors impacting antiretroviral drug adherence in a Nigerian tertiary hospital. J Pharmacol Pharmacother 2012;3:138-42.

40. Shaahu VN, Lawoyin TO, Sangowawa AO. Adherence to highly active antiretroviral therapy (HAAT) at a Federal Medical Centre. Afr J Med Med Sci 2008;37:29-36.

41. Uzochukwu BSC, Onwujekwe OE, Onoka AC, et al. Determinants of non-adherence to subsidized anti-retroviral treatment in southeast Nigeria. Health Policy Plan 2009;24:189-96.

42. Marcellin F, Boyer S, Protopopescu C, et al. Determinants of unplanned antiretroviral treatment interruptions among people living with HIV in Yaoundé, Cameroon (EVAL survey, ANRS 12-116). Trop Med Int Health 2008;13:1470-8.

43. Negash T, Ehlers V. Personal factors influencing patients' adherence to ART in Addis Ababa, Ethiopia. J Assoc Nurses AIDS Care 2013:24:530-8.

44. Maqutu D, Zewotir T, North D, et al. Factors affecting first-month adherence to antiretroviral therapy among HIV-positive adults in South Africa. Afr J AIDS Res 2010;9:117-24.

45. Maqutu D, Zewotir T. Optimal HAART adherence over time and time interval between successive visits: their association and determinants. AIDS Care 2011;23:1417-24.

46. Kekwaletswe C, Morojele N. Alcohol use, antiretroviral therapy adherence, and preferences regarding an alcohol-focused adherence intervention in patients with human immunodeficiency virus. Patient Prefer Adherence 2014;8:401-13.

47. Naidoo P, Peltzer K, Louw J, et al. Predictors of tuberculosis (TB) and antiretroviral (ARV) medication non-adherence in public primary care patients in South Africa: a cross sectional study. BMC Public Health 2013;13:396-406.

48. Ndiaye M, Nyasulu $\mathrm{P}, \mathrm{Nguyen} \mathrm{H}$, et al. Risk factors for suboptimal antiretroviral therapy adherence in HIV-infected adolescents in Gaborone, Botswana: a pilot cross-sectional study. Patient Prefer Adherence 2013;7:891-5

49. Sasaki $Y$, Kakimoto $\mathrm{K}$, Dube $\mathrm{C}$, et al. Adherence to antiretroviral therapy (ART) during the early months of treatment in rural Zambia: influence of demographic characteristics and social surroundings of patients. Ann Clin Microbiol Antimicrob 2012;11:34.

50. Bastard M, Fall M, Lanièce I, et al. Revisiting long-term adherence to highly active antiretroviral therapy in Senegal using latent class analysis. J Acquir Immune Defic Syndr 2011;57:55-61.

51. Nwauche C, Erhabor O, Ejele O, et al. Adherence to antiretroviral therapy among HIV-infected subjects in a resource-limited setting in the Niger Delta of Nigeria. Afr $J$ Health Sci 2006;13:13-17.

52. Unge C, Södergård B, Marrone G, et al. Long-term adherence to antiretroviral treatment and program drop-out in a high-risk urban setting in sub-Saharan Africa: a prospective cohort study. PLOS ONE 2010;5:e13613.

53. Birbeck GL, Kvalsund MP, Byers PA, et al. Neuropsychiatric and socioeconomic status impact antiretroviral adherence and mortality in rural Zambia. Am J Trop Med Hyg 2011;85:782-9.

54. Alakija KS, Fadeyi A, Ogunmodede JA, et al. Factors influencing adherence to antiretroviral medication in Ilorin, Nigeria. J Int Assoc Physicians AIDS Care (Chic) 2010;9:191-5.

55. Graham SM, Mugo $P$, Gichuru $E$, et al. Adherence to antiretroviral therapy and clinical outcomes among young adults reporting high-risk sexual behavior, including men who have sex with men, in coastal Kenya. AIDS Behav 2013;17:1255-65.

56. Mûnene E, Ekman B. Association between patient engagement in HIV care and antiretroviral therapy medication adherence: cross-sectional evidence from a regional HIV care center in Kenya AIDS Care 2015;27:378-86.

57. Erah $\mathrm{P}$, Arute J. Adherence of HIV/AIDS patients to antiretroviral therapy in a tertiary health facility in Benin City. Afr J Pharm Pharmacol 2008;2:145-52.

58. Peltzer K, Friend-du Preez N, Ramlagan S, et al. Antiretroviral treatment adherence among HIV patients in KwaZulu-Natal, South Africa. BMC Public Health 2010;10:111.

59. Afolabi L, ljadunola KT, Fatusi AO, et al. Determinants of adherence to antiretroviral drugs among people living with HIV/AIDS in Ife-ljesa Zone of Osun State, Nigeria. Afr J Prim Health Care Fam Med 2009;1:6-11.
60. Hegazi A, Bailey RL, Ahadzie B, et al. Literacy, education and adherence to antiretroviral therapy in the Gambia. AIDS Care 2010;22:1340-5

61. Bhat VG, Ramburuth $M$, Singh $M$, et al. Factors associated with poor adherence to anti-retroviral therapy in patients attending a rural health centre in South Africa. Eur J Clin Microbiol Infect Dis 2010;29:947-53.

62. Weiser S, Wolfe W, Bangsberg D, et al. Barriers to antiretroviral adherence for patients living with HIV infection and AIDS in Botswana. J Acquir Immune Defic Syndr 2003;34:281-8.

63. Eholié S, Tanon A, Polneau S, et al. Field adherence to highly active antiretroviral therapy in HIV-infected adults in Abidjan, Côte d'Ivoire. J Acquir Immune Defic Syndr 2007:45:355-8.

64. Beyene KA, Gedif T, Gebre-Mariam T, et al. Highly active antiretroviral therapy adherence and its determinants in selected hospitals from south and central Ethiopia. Pharmacoepidemiol Drug Saf 2009;18:1007-15.

65. Boyer S, Clerc I, Bonono C-R, et al. Non-adherence to antiretroviral treatment and unplanned treatment interruption among people living with HIV/AIDS in Cameroon: Individual and healthcare supply-related factors. Soc Sci Med 2011;72:1383-92.

66. Idindili B, Jullu B, Mugusi F, et al. A case-control study of factors associated with non-adherent to antiretroviral therapy among HIV infected people in Pwani Region, eastern Tanzania. Tanzan $J$ Health Res 2012;14:194-203.

67. Lyimo RA, de Bruin M, van den Boogaard J, et al. Determinants of antiretroviral therapy adherence in northern Tanzania: a comprehensive picture from the patient perspective. BMC Public Health 2012;12:716.

68. Lyimo RA, Stutterheim SE, Hospers HJ, et al. Stigma, disclosure, coping, and medication adherence among people living with HIV/ AIDS in Northern Tanzania. AIDS Patient Care STDS 2014;28:98-105

69. Mbonye M, Seeley J, Ssembajja F, et al. Adherence to antiretroviral therapy in Jinja, Uganda: a six-year follow-up study. PLoS ONE 2013;8:e78243.

70. Medley A, Seth P, Pathak S, et al. Alcohol use and its association with HIV risk behaviors among a cohort of patients attending HIV clinical care in Tanzania, Kenya, and Namibia. AIDS Care 2014:26:1288-97.

71. Musumari PM, Feldman MD, Techasrivichien T, et al. "If I have nothing to eat, I get angry and push the pills bottle away from me": a qualitative study of patient determinants of adherence to antiretroviral therapy in the Democratic Republic of Congo. AIDS Care 2013;25:1271-7.

72. Musumari PM, Wouters E, Kayembe PK, et al. Food insecurity is associated with increased risk of non-adherence to antiretroviral therapy among HIV-infected adults in the Democratic Republic of Congo: a cross-sectional study. PLOS ONE 2014;9:e85327.

73. Nakimuli-Mpungu E, Mojtabai R, Alexandre PK, et al. Lifetime depressive disorders and adherence to anti-retroviral therapy in HIV-infected Ugandan adults: a case-control study. J Affect Disord 2013;145:221-6.

74. Pefura-Yone EW, Soh E, Kengne AP, et al. Non-adherence to antiretroviral therapy in Yaounde: prevalence, determinants and the concordance of two screening criteria. J Infect Public Health 2013;6:307-15.

75. Roux $\mathrm{P}$, Kouanfack $\mathrm{C}$. Adherence to antiretroviral treatment in HIV-positive patients in the Cameroon context: promoting the use of medication reminder methods. J Acquir Immune Defic Syndr 2011;57(Suppl 1):S40-3.

76. Shumba C, Atuhaire L, Imakit R, et al. Missed doses and missed appointments: adherence to ART among adult patients in Uganda. ISRN AIDS 2013;2013:270914.

77. Do N, Phiri K, Bussmann $\mathrm{H}$, et al. Psychosocial factors affecting medication adherence among HIV-1 infected adults receiving combination antiretroviral therapy (cART) in Botswana. AIDS Res Hum Retroviruses 2010;26:685-91.

78. Kagee A, Nothling J, Coetzee B. The perspectives of users of antiretroviral therapy on structural barriers to adherence in South Africa. South African Fam Pract 2012;54:540-4.

79. Kip E, Ehlers VJ, van der Wal DM. Patients' adherence to anti-retroviral therapy in Botswana. J Nurs Scholarsh 2009;41:149-57.

80. Morojele NK, Kekwaletswe CT, Nkosi S. Associations between alcohol use, other psychosocial factors, structural factors and antiretroviral therapy (ART) adherence among South African ART recipients. AIDS Behav 2014;18:519-24. 
81. Nachega JB, Morroni C, Chaisson RE, et al. Impact of immune reconstitution inflammatory syndrome on antiretroviral therapy adherence. Patient Prefer Adherence 2012;6:887-91.

82. Nam SL, Fielding $\mathrm{K}$, Avalos A, et al. The relationship of acceptance or denial of HIV-status to antiretroviral adherence among adult HIV patients in urban Botswana. Soc Sci Med 2008;67:301-10.

83. Penn C, Watermeyer J, Evans M. Why don't patients take their drugs? The role of communication, context and culture in patient adherence and the work of the pharmacist in HIV/AIDS. Patient Educ Couns 2011;83:310-18

84. Sanjobo N, Frich JC, Fretheim A. Barriers and facilitators to patients' adherence to antiretroviral treatment in Zambia: a qualitative study. J Soc Asp HIV/AIDS 2008;5:136-43.

85. Skovdal M, Campbell C, Nhongo K, et al. Contextual and psychosocial influences on antiretroviral therapy adherence in rural Zimbabwe: towards a systematic framework for programme planners. Int J Health Plann Manage 2011;26:296-318.

86. Jaquet A, Ekouevi DK, Bashi J, et al. Alcohol use and non-adherence to antiretroviral therapy in HIV-infected patients in West Africa. Addiction 2010;105:1416-21.

87. Etienne M, Hossain M, Redfield R, et al. Indicators of adherence to antiretroviral therapy treatment among HIV/AIDS patients in 5 African countries. J Int Assoc Physicians AIDS Care (Chic) 2010;9:98-103.

88. Bezabhe WM, Chalmers L, Bereznicki LR, et al. Barriers and facilitators of adherence to antiretroviral drug therapy and retention in care among adult HIV-positive patients: a qualitative study from Ethiopia. PLOS ONE 2014;9:e97353.

89. Kisenyi RN, Muliira JK, Ayebare E. Religiosity and adherence to antiretroviral therapy among patients attending a public hospital-based HIV/AIDS clinic in Uganda. J Relig Health 2013;52:307-17

90. Lubinga SJ, Kintu A, Atuhaire J, et al. Concomitant herbal medicine and antiretroviral therapy (ART) use among HIV patients in Western Uganda: a cross-sectional analysis of magnitude and patterns of use, associated factors and impact on ART adherence. AIDS Care 2012;24:1375-83.

91. Thielman NM, Ostermann J, Whetten K, et al. Reduced adherence to antiretroviral therapy among HIV-infected Tanzanians seeking cure from the Loliondo healer. J Acquir Immune Defic Syndr 2014:65:e104-9.

92. Tumwine $\mathrm{C}$, Neema S, Wagner $\mathrm{G}$. Reasons why high religiosity can co-exist with and precipitate discontinuation of anti-retroviral therapy among different HIV clients in Uganda: an exploratory study. Religions (Basel) 2012;3:817-32.

93. Watt MH, Maman S, Jacobson M, et al. Missed opportunities for religious organizations to support people living with HIV/ AIDS: findings from Tanzania. AIDS Patient Care 2009;23:389-94

94. Groh K, Audet CM, Baptista A, et al. Barriers to antiretroviral therapy adherence in rural Mozambique. BMC Public Health 2011;11:650.

95. Malangu N. Self-reported adverse effects as barriers to adherence to antiretroviral therapy in HIV-infected patients in Pretoria. South African Fam Pract 2008;50:49-49b.

96. Peltzer K, Friend-du Preez N, Ramlagan S, et al. Antiretrovirals and the use of traditional, complementary and alternative medicine by HIV patients in KwaZulu-Natal, South Africa: a longitudinal study. Afr J Tradit Complement Altern Med 2011;8:337-45.

97. Audu B, Morgan R, Rutter P. Qualitative exploration of the relationship between HIV/AIDS patients' experiences of clinical services and treatment adherence at Maitama District Hospital, Abuja, Nigeria. AIDS Care 2014;26:270-3.

98. Ekwunife OI, Oreh C, Ubaka CM. Concurrent use of complementary and alternative medicine with antiretroviral therapy reduces adherence to HIV medications. Int J Pharm Pract 2012;20:340-3.

99. Habib AG, Shepherd JC, Eng MK, et al. Adherence to anti retroviral therapy (ART) during Muslim Ramadan fasting. AIDS Behav 2009:13:42-5.

100. Oku A, Owoaje E, Oku O, et al. Prevalence and determinants of adherence to highly active anti-retroviral therapy amongst people living with HIV/AIDS in a rural setting in South-South Nigeria. Afr J Reprod Health 2014;18:133-44.

101. Rasmussen DN, da Silva Té D, Rodkjaer L, et al. Barriers and facilitators to antiretroviral therapy adherence among patients with HIV in Bissau, Guinea-Bissau: a qualitative study. Afr J AIDS Res 2013;12:1-8.
102. Nyanzi-Wakholi B, Lara AM, Watera C, et al. The role of HIV testing, counselling, and treatment in coping with HIV/AIDS in Uganda: a qualitative analysis. AIDS Care 2009;21:903-8.

103. Talam NC, Gatongi $P$, Rotich J, et al. Factors affecting antiretroviral drug adherence among HIV/AIDS adult patients attending HIV/ AIDS clinic at Moi Teaching and Referral Hospital, Eldoret, Kenya. East Afr J Public Health 2008;5:74-8.

104. Byakika-Tusiime J, Oyugi JH, Tumwikirize WA, et al. Adherence to HIV antiretroviral therapy in HIV+ Ugandan patients purchasing therapy. Int J STD AIDS 2005;16:38-41.

105. Ngarina M, Popenoe R, Kilewo C, et al. Reasons for poor adherence to antiretroviral therapy postnatally in HIV-1 infected women treated for their own health: experiences from the Mitra Plus study in Tanzania. BMC Public Health 2013;13:450.

106. Aboubacrine SA, Niamba $P$, Boileau C, et al. Inadequate adherence to antiretroviral treatment and prevention in hospital and community sites in Burkina Faso and Mali: a study by the ATARAO group. Int J STD AIDS 2007;18:741-7.

107. Hardon AP, Akurut D, Comoro $C$, et al. Hunger, waiting time and transport costs: time to confront challenges to ART adherence in Africa. AIDS Care 2007;19:658-65.

108. Gusdal AK, Obua C, Andualem T, et al. Voices on adherence to ART in Ethiopia and Uganda: a matter of choice or simply not an option? AIDS Care 2009;21:1381-7.

109. Martin F, Kiwanuka T, Kawuma R, et al. Tasks and strategies of self-management of living with antiretroviral therapy in Uganda. AIDS Patient Care STDS 2013;27:697-706.

110. Nyanzi-Wakholi B, Lara AM, Munderi P, et al. The charms and challenges of antiretroviral therapy in Uganda: the DART experience. AIDS Care 2012;24:137-42.

111. Ramadhani HO, Thielman NM, Landman KZ, et al. Predictors of incomplete adherence, virologic failure, and antiviral drug resistance among HIV-infected adults receiving antiretroviral therapy in Tanzania. Clin Infect Dis 2007;45:1492-8.

112. Tuller DM, Bangsberg DR, Senkungu J, et al. Transportation costs impede sustained adherence and access to HAART in a clinic population in southwestern Uganda: a qualitative study. AIDS Behav 2010;14:778-84.

113. Watt MH, Maman S, Earp JA, et al. "It's all the time in my mind": facilitators of adherence to antiretroviral therapy in a Tanzanian setting. Soc Sci Med 2009;68:1793-800.

114. Aspeling HE, van Wyk NC. Factors associated with adherence to antiretroviral therapy for the treatment of HIV-infected women attending an urban care facility. Int $J$ Nurs Pract 2008;14:3-10.

115. Goudge J, Ngoma B. Exploring antiretroviral treatment adherence in an urban setting in South Africa. J Public Health Policy 2011;32 (Suppl 1):S52-64.

116. Ross AJ, Aung M, Campbell L, et al. Factors that positively influence adherence to antiretroviral therapy by HIV and/or AIDS patients and their caregivers. Afr J Prim Health Care Fam Med 2011;3:196-201.

117. Oku AO, Owoaje ET, Ige OK, et al. Prevalence and determinants of adherence to HAART amongst PLHIV in a tertiary health facility in south-south Nigeria. BMC Infect Dis 2013:13:401.

118. Weiser S, Tuller D, Frongillo E, et al. Food insecurity as a barrier to sustained antiretroviral therapy adherence in Uganda. PLOS ONE 2010;5:e10340.

119. Grant E, Logie D, Masura M, et al. Factors facilitating and challenging access and adherence to antiretroviral therapy in a township in the Zambian Copperbelt: a qualitative study. AIDS Care 2008;20:1155-60.

120. Murray LK, Semrau K, McCurley E, et al. Barriers to acceptance and adherence of antiretroviral therapy in urban Zambian women: a qualitative study. AIDS Care 2009;21:78-86.

121. Markos E, Worku A, Davey G. Adherence to ART in PLWHA and Yirgalem Hospital, South Ethiopia. Ethiopian J Health Dev 2009:174-9.

122. Bhagwanjee A, Govender K, Akintola O, et al. Patterns of disclosure and antiretroviral treatment adherence in a South African mining workplace programme and implications for HIV prevention. Afr J AIDS Res 2011;10(Suppl 1):357-68.

123. Senkomago V, Guwatudde D, Breda M, et al. Barriers to antiretroviral adherence in HIV-positive patients receiving free medication in Kayunga, Uganda. AIDS Care 2011;23:1246-53.

124. Muyingo S, Walker A, Reid A, et al. Patterns of individual and population-level adherence to antiretroviral therapy and risk factors for poor adherence in the first year of the DART trial in Uganda and. J Acquir Immune Defic Syndr 2008;48:468-75. 
125. Matovu SN, La cour K, Hemmingsson H. Narratives of Ugandan women adhering to HIV/AIDS medication. Occup Ther Int 2012;19:176-84.

126. Tessema B, Biadglegne F, Mulu A, et al. Magnitude and determinants of nonadherence and nonreadiness to highly active antiretroviral therapy among people living with HIV/AIDS in Northwest Ethiopia. AIDS Res Ther 2010;7:1-8.

127. Van Griensven J, Zachariah R, Mugabo J, et al. Weight loss afte the first year of stavudine-containing antiretroviral therapy and its association with lipoatrophy, virological failure, adherence and CD4 counts at primary health care level in Kigali, Rwanda. Trans $R$ Soc Trop Med Hyg 2010;104:751-7.

128. Bhengu BR, Ncama BP, Mclnerney PA, et al. Symptoms experienced by HIV-infected Individuals on antiretrovira therapy in KwaZulu-Natal, South Africa. Appl Nurs Res 2011:24:1-9.

129. Obirikorang C, Selleh PK, Abledu JK, et al. Predictors of adherence to antiretroviral therapy among HIV/AIDS patients in the Upper West Region of Ghana. ISRN AIDS 2013;2013:1-7.

130. Sow P, Toure K, Coume M, et al. Predictors of ART adherence among HIV infected individuals in Dakar, Senegal. J Med Med Sci 2012;3:212-16.

131. Nachega JB, Knowlton AR, Deluca A, et al. Treatment supporter to improve adherence to antiretroviral therapy in HIV-infected South African adults. A qualitative study. J Acquir Immune Defic Syndr 2006;43(Suppl 1):S127-33.

132. Carlucci JG, Kamanga A, Sheneberger R, et al. Predictors of adherence to antiretroviral therapy in rural Zambia. J Acquir Immune Defic Syndr 2008;47:615-22.

133. Etard J-F, Lanièce I, Fall MBK, et al. A 84-month follow up of adherence to HAART in a cohort of adult Senegalese patients. Trop Med Int Health 2007;12:1191-8.

134. Jones D, Cook R, Spence A. Antiretroviral therapy in Zambia: do partners on ART enhance adherence? J Int Assoc Provid AIDS Care 2014;13:497-500.

135. Van Oosterhout JJ, Bodasing N, Kumwenda JJ, et al. Evaluation of antiretroviral therapy results in a resource-poor setting in Blantyre, Malawi. Trop Med Int Health 2005;10:464-70.

136. Lanièce I, Ciss M, Desclaux A, et al. Adherence to HAART and its principal determinants in a cohort of Senegalese adults. AIDS 2003;17:S103-8.

137. Bajunirwe F, Arts EJ, Tisch DJ, et al. Adherence and treatment response among HIV-1-infected adults receiving antiretroviral therapy in a rural government hospital in Southwestern Uganda. $J$ Int Assoc Physicians AIDS Care 2009;8:139-47.

138. Olowookere S, Fatiregun AA, Akinyemi JO, et al. Prevalence and determinants of nonadherence to highly active antiretroviral therapy among people living with HIV/AIDS in Ibadan, Nigeria. J Infect Dev Ctries 2008;2:369-72.

139. Birbeck GL, Chomba E, Kvalsund M, et al. Antiretroviral adherence in rural Zambia: the first year of treatment availability. Am J Trop Med Hyg 2009;80:669-74.

140. Amberbir A, Woldemichael K, Getachew S, et al. Predictors of adherence to antiretroviral therapy among HIV-infected persons: a prospective study in Southwest Ethiopia. BMC Public Health 2008;8:1-9.

141. Tiyou A, Belachew T, Alemseged F, et al. Predictors of adherence to antiretroviral therapy among people living with HIV/AIDS in resource-limited setting of southwest Ethiopia. AIDS Res Ther 2010;7:1-10.

142. Whetten K, Shirey K, Pence B, et al. Trauma history and depression predict incomplete adherence to antiretroviral therapies in a low income country. PLOS ONE 2013;8:1-7.

143. Adewuya AO, Afolabi MO, Ola BA, et al. The effect of psychological distress on medication adherence in persons with HIV infection in Nigeria. Psychosomatics 2010;51:68-73.

144. Okoror TA, Falade CO, Olorunlana A, et al. Exploring the cultural context of HIV stigma on antiretroviral therapy adherence among people living with HIV/AIDS in southwest Nigeria. AIDS Patient Care STDS 2013;27:55-64.

145. Omosanya OE, Elegbede OT, Agboola SM, et al. Effects of stigmatization/discrimination on antiretroviral therapy adherence among HIV-infected patients in a rural tertiary medical center in Nigeria. J Int Assoc Provid AIDS Care 2014;13:260-3.

146. Belenky NM, Cole SR, Pence BW, et al. Depressive symptoms, HIV medication adherence, and HIV clinical outcomes in Tanzania: a prospective, observational study. PLOS ONE 2014;9:1-5.

147. Wroe EB, Hedt-Gauthier BL, Franke MF, et al. Depression and patterns of self-reported adherence to antiretroviral therapy in Rwanda. Int J STD AIDS 2014;1-5.
148. Nel A, Kagee A. The relationship between depression, anxiety and medication adherence among patients receiving antiretroviral treatment in South Africa. AIDS Care 2013;25:948-55.

149. Olisah VO, Baiyewu O, Sheikh TL. Adherence to highly active antiretroviral therapy in depressed patients with HIV/AIDS attending a Nigerian university teaching hospital clinic. Afr J Psychiatry 2010;13:275-9.

150. Nakimuli-Mpungu E, Mutamba B, Othengo M, et al. Psychological distress and adherence to highly active anti-retroviral therapy (HAART) in Uganda: a pilot study. Afr Health Sci 2009;9(Suppl 1):2-7.

151. Brinkley-Rubinstein L, Chadwick C, Graci M. The connection between serious life events, anti-retroviral adherence, and mental health among HIV-positive individuals in the Western Cape, South Africa. AIDS Care 2013;25:1581-5.

152. Skovdal M, Campbell C, Nyamukapa C, et al. When masculinity interferes with women's treatment of HIV infection: a qualitative study about adherence to antiretroviral therapy in Zimbabwe. J Int AIDS Soc 2011;14:29

153. Abaasa AM, Todd J, Ekoru K, et al. Good adherence to HAART and improved survival in a community HIV/AIDS treatment and care programme: the experience of The AIDS Support Organization (TASO), Kampala, Uganda. BMC Health Serv Res 2008;8:1-10.

154. Goldman JD, Cantrell RA, Mulenga LB, et al. Simple adherence assessments to predict virologic failure among HIV-infected adults with discordant immunologic and clinical responses to antiretroviral therapy. AIDS Res Hum Retroviruses 2008;24:1031-5.

155. Ukwe C, Ekwunife O, Udeogaranya O, et al. Self-reported adherence to HAART in South-Eastern Nigeria is related to patients' use of pill box. J Soc Asp HIV AIDS 2010;7:10-15

156. Stubbs BA, Micek MA, Pfeiffer JT, et al. Treatment partners and adherence to HAART in Central Mozambique. AIDS Care 2009;21:1412-19.

157. Abah IO, Ojeh VB, Musa J, et al. Clinical utility of pharmacy-based adherence measurement in predicting Virologic Outcomes in an Adult HIV-Infected Cohort in Jos, North Central Nigeria. J Int Assoc Provid AIDS Care 2014;1-7.

158. Ford N, Darder M, Spelman T, et al. Early adherence to antiretroviral medication as a predictor of long-term HIV virological suppression: five-year follow up of an observational cohort. PLoS ONE 2010;5:1-4.

159. Kebede A, Wabe NT. Medication adherence and its determinants among patients on concomitant tuberculosis and antiretroviral therapy in South West Ethiopia. N Am J Med Sci 2012;4:67-71.

160. Mayanja B, Ekoru K, Namugenyi H, et al. Patients' worries before starting antiretroviral therapy and their association with treatment adherence and outcomes: a prospective study in rural Uganda, 2004. BMC Res Notes 2013;6:1-8.

161. Mitiku H, Abdosh T, Teklemariam Z. Factors affecting adherence to antiretroviral treatment in Harari national regional state, eastern Ethiopia. ISRN AIDS 2013;2013:1-7.

162. Ncama BP, Mclnerney PA, Bhengu BR, et al. Social support and medication adherence in HIV disease in KwaZulu-Natal, South Africa. Int J Nurs Stud 2008;45:1757-63.

163. Oyugi JH, Byakika-Tusiime J, Ragland K, et al. Treatment interruptions predict resistance in HIV-positive individuals purchasing fixed-dose combination antiretroviral therapy in Kampala, Uganda. AIDS 2007;21:965-71.

164. Unge $C$, Södergård $B$, Ekström AM, et al. Challenges for scaling up ART in a resource-limited setting: a retrospective study in Kibera, Kenya. J Acquir Immune Defic Syndr 2009;50:397-402.

165. Tadesse WT, Mekonnen AB, Tesfaye WH, et al. Self-reported adverse drug reactions and their influence on highly active antiretroviral therapy in HIV infected patients: a cross sectional study. BMC Pharmacol Toxicol 2014;15:32

166. Knobel $\mathrm{H}$, Alonso J, Casado JL, et al. Validation of a simplified medication adherence questionnaire in a large cohort of HIV-infected patients: the GEEMA Study. AIDS 2002;16:605-13.

167. Morisky DE, Ang A, Krousel-Wood MW. Reliability of a medication adherence measure in an outpatient setting. Am J Med Sci 2005;330:128-33.

168. Oyugi JH, Byakika-Tusiime J, Charlebois ED, et al. Multiple validated measures of adherence indicate high levels of adherence to generic HIV antiretroviral therapy in a resource-limited setting. J Acquir Immune Defic Syndr 2004;36:1100-2.

169. Giordano TP, Guzman D, Clark R, et al. Measuring adherence to antiretroviral therapy in a diverse population using a visual analogue scale. HIV Clin Trials 2004;5:74-9.

170. Walsh JC, Mandalia S, Gazzard BG. Responses to a 1 month self-report on adherence to antiretroviral therapy are consistent with 
electronic data and virological treatment outcome. AIDS 2002:16:269-77.

171. Maneesriwongul WL, Tulathong S, Fennie KP, et al. Adherence to antiretroviral medication among HIV-positive patients in Thailand. J Acquir Immune Defic Syndr 2006;43(Suppl 1):S119-22.

172. Kelly JD, Hubenthal EA, Lurton G, et al. Multiple self-report measures of antiretroviral adherence correlated in Sierra Leone, but did they agree? Int J STD AIDS 2013;24:931-7.

173. Decroo T, Koole O, Remartinez D, et al. Four-year retention and risk factors for attrition among members of community ART groups in Tete, Mozambique. Trop Med Int Health 2014;19:514-21.

174. Rasschaert F, Telfer B, Lessitala F, et al. A qualitative assessment of a community antiretroviral therapy group model in Tete, Mozambique. PLOS ONE 2014;9:e91544.

175. Peltzer K, Phaswana-mafuya N, Petros G. Hazardous alcohol use among persons living with human immunodeficiency virus infection in the Eastern Cape, South Africa. J Psychol Africa 2009;19:247-52.
176. WHO Brief Intervention Study Group. A cross-national trial of brief interventions with heavy drinkers. Am J Public Health 1996;86:948-55.

177. Dowshen N, Kuhns LM, Johnson A, et al. Improving adherence to antiretroviral therapy for youth living with HIV/AIDS: a pilot study using personalized, interactive, daily text message reminders. J Med Internet Res 2012;14:e51.

178. Petersen I, Hanass Hancock J, Bhana A, et al. A group-based counselling intervention for depression comorbid with HIV/AIDS using a task shifting approach in South Africa: a randomized controlled pilot study. J Affect Disord 2014;158:78-84.

179. Sanne I, Orrell C, Fox MP, et al. Nurse versus doctor management of HIV-infected patients receiving antiretroviral therapy (CIPRA-SA): a randomised non-inferiority trial. Lancet 2010;376:33-40.

180. Bemelmans M, Van Den Akker T, Ford N, et al. Providing universal access to antiretroviral therapy in Thyolo, Malawi through task shifting and decentralization of HIV/AIDS care. Trop Med Int Health 2010;15:1413-20. 